IBT Journal of Business Studies (IBT-JBS)

E-ISSN: 2409-6520; P-ISSN: 2414-8393

Volume 16:, 58-70 (2020)

DOI: 10.46745/ILMA.jbs.2020.161.01

\title{
Evaluating the Impact of Occupational Stress on Female Nurses Performance in National Institute of Cardiovascular Diseases, Karachi
}

\author{
Received: 9-Mar-2020 | Accepted: 18-Jul-2020
}

Zulfiqar Ali $^{1^{*}}$ iD $\mid$ Syed Kashan Ali Shah² iD $\mid$ Syed Shabib-ul-Hasan³

\begin{abstract}
The study aimed to evaluate the effect of factors of occupational stress on the performance of NICVD nurses.In this concern, the research design of the study was quantitative, therefore, a close-ended survey-questionnaire was used. The factors included long-duty hours, perfectionism, high stakes, lack of choice, emotions draining situation and little support from the management while the dependent variable was employee performance. The researcher accumulated data from 287 female nurses and analysed it using correlation and regression. Based on the accumulated data, it was inferred that the variables, including long-hours duty, little support from management and lack of choice were found to be highly significant in affecting the performance of female nurses working at NICVD. However, the study was limited to the geographical bounds of Karachi and the specific institute considered in this aspect was the National Institute of Cardiovascular Diseases (NICVD). Nonetheless, it is significant as there was no research conducted on NICVD, Karachi specifically prior to this research underpinning occupational stress in female nurses.
\end{abstract}

Keywords: Occupational stress, nurses, NICVD, employee perform, Karachi

JEL Classification: $H 51, H 75, I 11, I 12, K 32$

\section{Author's Affiliation: \\ Institution: \\ University of Karachi ${ }^{1,2,3}$ \\ Country: \\ Pakistan \\ Corresponding Author's Email: *zashadab@gmail.com}

The material presented by the author(s) does not necessarily portray the view point of the editors and the management of the ILMA University, Pakistan.

2409-6520 (Online) 2414-8393 (Print) (C2020, published by the ILMA University, Pakistan.

This is open access article under the @- $\odot$ license. https://creativecommons.org/licenses/by/4.0/ 


\section{1) INTRODUCTION}

The viability and sustainability of the organisations in their respective industries are highly dependent on the performance of its employees. However, the study of Mahiri and Orwa(2016) asserted that there are numerous factors that can be deemed as constraints resulting in an adverse effect on the performance of the employees. In this concern, the study highlighted one of the key elements contributing to the failing performances- occupational stress. The study conducted by Beehr(2014) explained the phenomenon of occupational stress by stating that the stress associated with the jobs that stem from the unrealistic expectations, workload, unanticipated responsibilities, impeding one's ability to endure, and sometimes, self-constraints and lack of self-confidence are referred to as occupational stress. There are a number of factors that add to the occupational stress- long working hours, seeking perfectionism, limited choice, minimal external support, and emotionally draining situations to name a few (Shrivastava\& Shukla, 2017). Considering the relevancy of the subject, various studies have underpinned the topic of occupational stress in different contexts and industries due to variability in the dynamism and different industrial structures. In this concern, the following study is focused to analyse the occupational stress in the case of National Institute of Cardiovascular Diseases (NICVD), Karachi and the factors of the occupational stress contributing to the declining performance. The study is determined to explore the case of female nurses working at NICVD and the occupational stress they are battling with. One of the motivations behind conducting this research is the evidence regarding growing stress amongst the nurses which is turning to be severe with time and affecting the personal and professional lives of them undesirably (Badil, Ali \& Siddiqui, 2017). In this aspect, exploring the factors and evaluating them to provide relevant recommendations would be significant for the nurses. Since this research is underpinning NICVD, therefore, the relevance and significance increase for the institution and the stakeholders associated with it even more.

\section{1) AIM AND OBJECTIVES OF THE STUDY}

The primary aim of the study is to analyse the effect of occupational stress on employee performance along with the factors contributing to it specifically in NICVD, Karachi. In this concern, the following objectives have been made:

To determine the factors affecting employee performance in NICVD due to occupational stress

- To determine the extent to which occupational stress influence job performance

- To suggest the corrective actions to enhance employee morale as well as job performance

- To find a solution that enables the management to resolve stress-related issues in NICVD.

\subsection{RESEARCH QUESTION}

Considering the aim and objectives, the essential research question that this study puts forth has been presented as follows: 
IBT JOURNAL OF BUSINESS STUDIES (IBT-JBS) Volume 16 Issue 1, 2020

"What is the effect of the factors contributing to occupational stress on employee performance in the case of female nurses serving at NICVD?"

\section{2) LITERATURE REVIEW}

\section{1) OCCUPATIONAL STRESS}

In response to the pressure and challenges posed by the organisations, the physical and specifically mental state of the employee's experience change and such phenomenon is referred to as occupational stress (Mustafa et al., 2015). Quick and Henderson (2016) added by mentioning occupational stress as a chronic condition which can become toxic to the employees They further noted that in the last 40 years, the rise in the occupational stress become alarming whereas Mohajan (2012) pointed towards its absence in literature in the 19th century. Recently researchers considered, the causes were also identified by the authors as they consider global financial crises and the incremental incline of the organisation towards globalisation as the root cause of occupational stress. The phenomenon is irrespective of the domain of the work or country. The growth in global communication due to advancement in technology and workplace diversity also proved to be the causes of workplace stress (Schnall, Dobson \& Landsbergis, 2016).

\subsection{FACTORS CONTRIBUTING TO OCCUPATIONAL STRESS}

El Shikieri and Musa (2012) highlighted a dominant factor contributing to occupational stress- long-duty hours. The study asserted that when the duty hours are exceeded due to extensive workload, the employees become unable to focus on their personal lives which ignite a sense of dissatisfaction and change in the state of mind resulting in stress. The urge to attain perfectionism in the work also contributes to the occupational stress as Kanten andYesiltas (2015) explained. Elaborating further, the study stated that perfection can be self-oriented or some external forces impose on employees to deliver perfect work. In this case, the employers attempt to take the maximum benefit of the employees irrespective of their mental or physical health and put unrealistic demands of perfect wok in front of them. Considering the stress levels, the risk increases of mood swings and other mental health problems. The study conducted on nurses professed that high stakes add to occupational stress resulting in mood-shifts in nurses due to which, the patients suffer (Botha, Gwin\&Purpora, 2015).

The studies of Chatzigianni et al., (2018); Bakker and Demerouti (2017) stated that lack of occupational choice also contributes to the occupational stress. However, this can vary with respect to job roles or within a job role. The study explained that in case of unwanted job role which the employee is compelled to do due to external conditions, i.e. financial conditions, the stress level increases. In addition, the stringent organisational environment with limited autonomy in decision-making limits the scope of a role and adds to the stress (Katić et al., 2019). The research of Khamisa et al., (2015) identified another factor as well which is emotions draining situations specifically in the case of nurses because of the encounters like, injured patients, dead bodies, traumatic families and similar instances. In addition, Lewig 
and Dollard (2003); and Golparvar, Kamkar andJavadian (2012) stated the deficient self-reciprocity by the institutions in response to organisational stressors lead to emotional exhaustion in the employees. This also implies that the management of the organisations extends minimal support to their employees. The accessibility issues to stress management in the institutions or firms by the employers affect the employees negatively resulting in occupational stress (Beheshtifar\&Nazarian, 2013)

\section{3) IMPACT OF OCCUPATIONAL STRESS OF EMPLOYEE PERFORMANCE}

A moderate pressure posed by the employers on their employees works out most of the times in a positive manner because it enhances the sense of responsibility (Mahiri\&Orwa, 2016). In this case, the study further pressed that when the stressor by the employers or the organisation increases then, the positive effect turns to be adverse for the employee and ultimately on the organisational productivity. Another study conducted by Amin, Khattak and Khan(2018) stated that occupational stress is associated with job commitment and satisfaction. The increment in the dissatisfaction level in relation to jobs result in burnout and high turnover rates (Wu, Hu\& Zheng, 2019). In addition, the individual performance suffers as well with the increase in absenteeism, weakened decisions, missing deadlines and similar instances (Ratnawat\&Jha, 2014).

In the case of the healthcare section, the consequences of occupational stress worsen on employee performance. The study conducted by Badil, Ali and Siddique (2017) asserted that the negligence of the doctors or nurses can risk life and stress affecting the mental state of the medical practitioners can consequently result in form of medical errors. The stressors can create an imbalance in the life of the medical practitioners causing physical, and psychological problems impacting the performance negatively (Roland, 2014).

\section{4) THEORETICAL FRAMEWORK}

According to the study conducted by Beheshtifar and Nazarian (2013), in the context of occupational stress theory, the JDC (Job-demand-control) model was advocated. It underpins two contexts that are namely job control and job demand. In this concern, a psychological stressor is referred to as job demand where the task can be challenging or limited time is provided to finish the task. Concerning job control, it is further bifurcated into two aspects that are authoritative decision power and skill discretion. Hence, the model has highlighted the causes of the stress (stressors), factors affecting and their effect (strain).

\section{5) CONCEPTUAL MODEL OF THE STUDY}

The conceptual model of the study has been presented as follows in which the independent variable of the study is occupational stress and the dependent construct is employee performance. The figure has been presented as follows where the identified factors have been illustrated separately for testing. The independent 
variables of the study are long duty hours (El Shikieri\& Musa, 2012), perfectionism (Kanten\&Yesiltas, 2015), high stakes (Botha, Gwin\&Purpora, 2015), lack of choice (Chatzigianni et al., 2018), emotions draining situation (Khamisa et al., 2015), and little support from management (Beheshtifar\&Nazarian, 2013). The mentioned independent variables are depicting occupational stress. However, the dependent variable of the study is employee performance (Asamoah-Appiah\&Aggrey-Fynn, 2017).

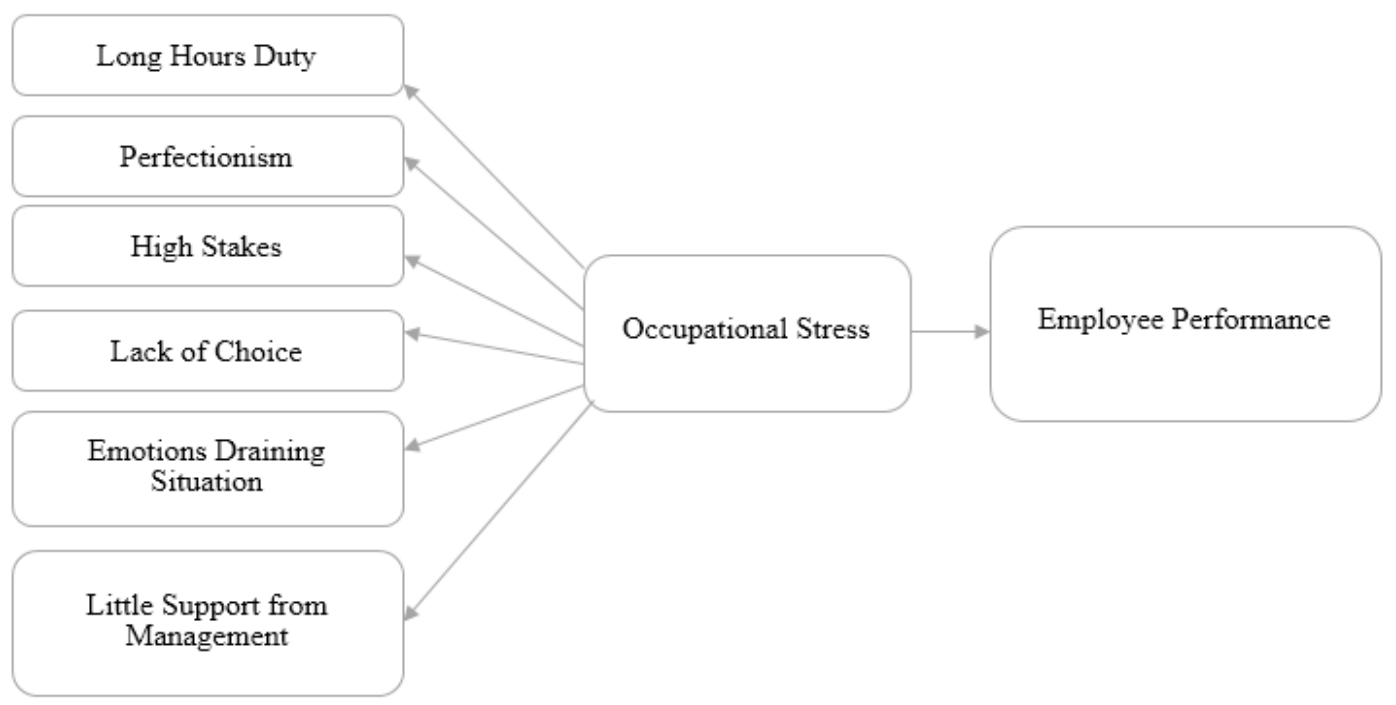

Figure 1: Conceptual Model of the Study

\section{6) CONSTRUCTION OF HYPOTHESES}

Considering the conceptual framework, the researcher has formulated following hypotheses underpinning the theories for testing with respect to female nurses in the emergency department of a cardiovascular hospital (NICVD).

H1: The effect of long-hours duty as a factor of occupational stress is significant on the employee performance

$\mathrm{H} 2$ : The effect of perfectionism as a factor of occupational stress is significant on the employee performance

H3: The effect of high stake as a factor of occupational stress is significant on the employee performance

H4: The effect of lack of choice as a factor of occupational stress is significant on the employee performance

H5: The effect of emotions draining situation at duty as a factor of occupational stress is significant on the employee performance

H6: The effect of little support from management as a factor of occupational stress is significant on the employee performance 


\section{3) RESEARCH METHODOLOGY}

The research design of the study was quantitative therefore, survey-questionnaire was used to attain the aim of the study. The researcher accumulated data from 287 nurses, however, considering the limited scope of the study, the researcher gathered data from the experienced nurses and those nurses as well who were working in NICVD rotationally. Those included undergraduate students, females enrolled in diploma and those females as well who were enrolled in certification while some were tutoring the nurses. The core reason was to increase the sample to gather sufficient data for testing. In this case, only those students were considered who at least worked rotationally in any department of NICVD. The study conducted by Fay andGerow (2013) asserted that a sample ranging between 200 and 300 is sufficient. Given this, the sampling technique considered in the study was purposive where nurses working in NICVD were considered and it is a non-probability sampling technique. On the other hand, the description implies the use of primary data to enrich the literature and provide practical implications to reduce occupational stress. Following the data collection, the researcher tested the reliability of the data using Cronbach Alpha. The study of Ursachi, Horodnic andZait(2015) inferred that the value of Cronbach Alpha should be exceeding 0.6. In this case, all the variables of the study have reliability statistic more than 0.6 indicating reliability and consistency of the scale (5-point Likert). The scale of the study ranged from strongly disagree to strongly agree which was modified from different studies as mentioned in the appendix. In addition, to analyse the data, demographic profiling, correlation and regression analysis were conducted on SPSS. The results of reliability statistics can be viewed in Table 1 .

\begin{tabular}{lr} 
Table 1: Reliability Statistics (Cronbach Alpha) \\
\hline Variables & Reliability Statistics \\
Long Hours Duty & 0.754 \\
Perfectionism & 0.677 \\
High Stakes & 0.705 \\
Lack of Choice & 0.772 \\
Emotions Draining Situation & 0.825 \\
Little Support from Management' & 0.703 \\
Employee Performance & 0.736 \\
\hline
\end{tabular}

\section{4) DATA ANALYSIS}

In this section, statistical evaluation has been done to assess the influence of identified factors pertaining to occupational stress on the performance of the nurses working at NICVD. Firstly, the analysis incorporates demographic profiling which is followed by correlation analysis. The study of Gogtay and Thatte (2017) stated that when two variables are evaluated for their relationship in a linear dimension, correlation is utilised. In addition, regression has been used further to analyse the impact of the identified factors of occupational stress on employee performance. This 
IBT JOURNAL OF BUSINESS STUDIES (IBT-JBS) Volume 16 Issue 1, 2020

section additionally includes a tabulated summary of the constructed hypotheses and discussion in relation to the findings of this study.

\section{1) DEMOGRAPHIC PROFILING}

The sample of the study comprised of all female members as the study is genderoriented. In addition, the sample comprised of $5.9 \%$ of the people aged less than 20 years, $61 \%$ were between 21 years to 30 years and $33.1 \%$ of the participants were above 30 years. In terms of working experience, $41.5 \%$ had less than 1 year of experience, $47.7 \%$ had experience ranging from 1 to 5 years and $10.5 \%$ had an experience of more than 5 years. Moreover, considering the marital status, $28.6 \%$ were single, $36.2 \%$ were married and $35.2 \%$ were divorced/ widowed. The results have been presented in Table 2:

Table 2: Demographic Profiling of the Respondents

\begin{tabular}{llrrr}
\hline Demographic Variables & Categories & Frequency & Percent & Valid Percent \\
& $<$ 20 years & 17 & 5.9 & 5.9 \\
& 21 to 30 years & 175 & 61.0 & 61.0 \\
& $>$ 30 years & 95 & 33.1 & 33.1 \\
\multirow{3}{*}{ Working Experience } & Less than 1 year & 120 & 41.5 & 41.5 \\
& 1 to 5 years & 137 & 47.7 & 47.7 \\
& $>$ 5 years & 30 & 10.5 & 10.5 \\
Marital Status & Single & 82 & 28.6 & 28.6 \\
& Married & 104 & 36.2 & 36.2 \\
& Divorced/ Widowed & 101 & 35.2 & 35.2 \\
\hline
\end{tabular}

\subsection{CORRELATION ANALYSIS}

The association of employee performance has been tested with the factors identified pertaining to occupational stress. The factors include long-duty hours, perfectionism, high stakes, lack of choice, emotions draining situation and little support from the management. The association of long-duty hours with the employee performance is computed to be negative, moderate and significant $(r=-0.352 ; \mathrm{p}$-value $=0.00<0.05)$. The relationship of perfectionism with the employee performance is computed to be negative, moderate and significant $(\mathrm{r}=-0.326 ; \mathrm{p}$-value $=0.00<0.05)$. The correlation of high stakes with the employee performance is computed to be negative, moderate and significant $(\mathrm{r}=-0.493 ; \mathrm{p}$-value $=0.00<0.05)$. The association of lack of choice with the employee performance is computed to be negative, moderate and significant $(\mathrm{r}=-0.372 ; \mathrm{p}$-value $=0.00<0.05)$. The correlation of emotions draining with the employee performance is computed to be negative, strongly moderate and significant $(\mathrm{r}=-0.538$; $\mathrm{p}$-value $=0.00<0.05)$. The relationship of little support from management with the employee performance is computed to be negative, strong and significant $(\mathrm{r}=-0.739 ; \mathrm{p}$-value $=0.00<0.05)$. The results can be viewed in Table 3. 


\begin{tabular}{|c|c|c|c|c|c|c|c|c|}
\hline & & Long & & & Lack & Emotions & $\begin{array}{c}\text { Little } \\
\text { Support } \\
\text { from }\end{array}$ & $\begin{array}{l}\text { Em- } \\
\text { ployee }\end{array}$ \\
\hline & & Hours & & High & of & Draining & Manage- & Perfor- \\
\hline & & Duty & Perfectionism & Stakes & Choice & Situation & ment' & mance \\
\hline \multirow{4}{*}{$\begin{array}{l}\text { Long } \\
\text { Hours } \\
\text { Duty }\end{array}$} & Pearson & 1 & $.497^{* *}$ & $.591^{* *}$ & $.464^{* *}$ & $.453^{* *}$ & $.446^{* *}$ & $-.352^{* *}$ \\
\hline & Correla- & & & & & & & \\
\hline & tion & & & & & & & \\
\hline & $\begin{array}{l}\text { Sig. } \\
\text { (2-tailed) }\end{array}$ & & 0.000 & 0.000 & 0.000 & 0.000 & 0.000 & 0.000 \\
\hline \multirow[t]{2}{*}{$\begin{array}{l}\text { Perfec- } \\
\text { tionism }\end{array}$} & $\begin{array}{l}\text { Pearson } \\
\text { Correla- } \\
\text { tion }\end{array}$ & $.497^{* *}$ & 1 & $.537^{* *}$ & $.552^{* *}$ & $.372^{* *}$ & $.363^{* *}$ & $-.326^{* *}$ \\
\hline & $\begin{array}{l}\text { Sig. } \\
\text { (2-tailed) }\end{array}$ & 0.000 & & 0.000 & 0.000 & 0.000 & 0.000 & 0.000 \\
\hline \multirow{3}{*}{$\begin{array}{l}\text { High } \\
\text { Stakes }\end{array}$} & Pearson & $.591^{* *}$ & $.537^{* *}$ & 1 & $.720^{* *}$ & $.591^{* *}$ & $.589^{* *}$ & $-.493^{* *}$ \\
\hline & $\begin{array}{l}\text { Correla- } \\
\text { tion }\end{array}$ & & & & & & & \\
\hline & $\begin{array}{l}\text { Sig. } \\
\text { (2-tailed) }\end{array}$ & 0.000 & 0.000 & & 0.000 & 0.000 & 0.000 & 0.000 \\
\hline \multirow{3}{*}{$\begin{array}{l}\text { Lack of } \\
\text { Choice }\end{array}$} & Pearson & $.464^{* *}$ & $.552^{* *}$ & $.720^{* *}$ & 1 & $.530^{* *}$ & $.526^{* *}$ & $-.372^{* *}$ \\
\hline & $\begin{array}{l}\text { Correla- } \\
\text { tion }\end{array}$ & & & & & & & \\
\hline & $\begin{array}{l}\text { Sig. } \\
\text { (2-tailed) }\end{array}$ & 0.000 & 0.000 & 0.000 & & 0.000 & 0.000 & 0.000 \\
\hline $\begin{array}{l}\text { Emo- } \\
\text { tions } \\
\text { Draining }\end{array}$ & $\begin{array}{l}\text { Pearson } \\
\text { Correla- } \\
\text { tion }\end{array}$ & $.453^{* *}$ & $.372^{* *}$ & $.591^{* *}$ & $.530^{* *}$ & 1 & $.705^{* *}$ & $-.538^{* *}$ \\
\hline $\begin{array}{l}\text { Situa- } \\
\text { tion }\end{array}$ & $\begin{array}{l}\text { Sig. } \\
\text { (2-tailed) }\end{array}$ & 0.000 & 0.000 & 0.000 & 0.000 & & 0.000 & 0.000 \\
\hline Little & Pearson & $.446^{* *}$ & $.363^{* *}$ & $.589^{* *}$ & $.526^{* *}$ & $.705^{* *}$ & 1 & $-.739^{* *}$ \\
\hline $\begin{array}{l}\text { Support } \\
\text { from }\end{array}$ & $\begin{array}{l}\text { Correla- } \\
\text { tion }\end{array}$ & & & & & & & \\
\hline $\begin{array}{l}\text { Manage- } \\
\text { ment' }\end{array}$ & $\begin{array}{l}\text { Sig. } \\
\text { (2-tailed) }\end{array}$ & 0.000 & 0.000 & 0.000 & 0.000 & 0.000 & & 0.000 \\
\hline
\end{tabular}


IBT JOURNAL OF BUSINESS STUDIES (IBT-JBS) Volume 16 Issue 1, 2020

$\begin{array}{llllllll}\text { Em- } & \text { Pearson } & -.352^{* *} & -.326^{* *} & -.493^{* *} & -.372^{* *} & -.538^{* *} & -.739^{* *} \\ \text { ployee } & \text { Correla- } & & & & & & \\ \text { Perfor- } & \text { tion } & & & & & & \\ \text { mance } & \text { Sig. } & 0.000 & 0.000 & 0.000 & 0.000 & 0.000 & 0.000 \\ & & & & & & \end{array}$

**. Correlation is significant at the 0.01 level (2-tailed).

\section{3) REGRESSION ANALYSIS}

The impact of factors of occupational stress on the performance of nurses has been computed using regression analysis. The effect of high stakes has been computed to be negative and significance on the employee performance $(B=-$ 0.086 ; $p$-value $=0.026<0.05$ ). The impact of lack of choice has been computed to be positive and significance on the employee performance $(B=-0.179 ; p$-value $=0.021<$ $0.05)$. In addition, the impact of little support from management is computed to be negative and significance on the employee performance $(B=-0.811 ; p$-value $=0.000<$ $0.05)$. However, the effect of other factors has been computed to be statistically insignificant because the p-value was above the threshold of $5 \%(0.05)$.

On the basis of f-statistics, the overall model is significant implying the significant effect of occupational stress on the performance of NICVD nurses (f-statistics $=$ $59.772 ; \mathrm{p}$-value $=0.000<0.05)$. In addition, the variance in all factors is explaining $56.14 \%$ variance in the employee performance concerning the NICVD nurses which is reduced to $55.20 \%$ after adjustments of the errors. Therefore, the model is found to be $56.14 \%$ fit. The results can be viewed in Table 4 .

Table 4: Regression Analysis

\begin{tabular}{lrrrr} 
& Coefficient $(\mathrm{B})$ & \multicolumn{1}{c}{ Error } & \multicolumn{1}{c}{$\mathrm{t}$} & \multicolumn{1}{c}{ Sig. } \\
(Constant) & $5.721^{* * *}$ & .125 & 45.778 & .000 \\
Long Hours Duty & .035 & .064 & .557 & .578 \\
Perfectionism & -.086 & .055 & -1.564 & .119 \\
High Stakes & $-.179 * *$ & .080 & -2.231 & .026 \\
Lack of Choice & $.181^{* *}$ & .078 & 2.320 & .021 \\
Emotions Draining Situation & -.017 & .066 & -.260 & .795 \\
Little Support from Management' & $-.811^{* * *}$ & .068 & -11.853 & .000 \\
F-statistics & 59.772 & & R-squared & $56.14 \%$ \\
Significance & .000 & & Adjusted & \\
& & & R-squared & $55.20 \%$ \\
\hline
\end{tabular}


$* * *$ : significant at $1 \% ; * *$ : at $5 \% ; *$ : at $10 \%$

\subsection{SUMMARY OF HYPOTHESES}

In accordance with the findings of the study, the summary of the tested propositions in case if NICVD nurses can be viewed as follows where three hypotheses statements are statistically supported whereas, three are found to be unsupported. The summary has been presented in Table 5 .

Table 5: Hypotheses Assessment Summary

\section{Hypotheses Statements}

Decision

H1: The effect of long-hours duty as a factor of occupational stress is significant on the employee performance

Unsupported

$\mathrm{H} 2$ : The effect of perfectionism as a factor of occupational stress is significant on the employee performance

Unsupported

H3: The effect of high stake as a factor of occupational stress is significant on the employee performance

Supported

H4: The effect of lack of choice as a factor of occupational stress is

significant on the employee performance

Supported

H5: The effect of emotions draining situation at duty as a factor of occupational stress is significant on the employee performance

Unsupported

H6: The effect of little support from management as a factor of occupational stress is significant on the employee performance

Supported

\section{5) DISCUSSION}

The study aimed to analyse the effect of occupational stress on the performance of NICVD nurses. However, firstly, different factors were explored through literature review where long-duty hours, perfectionism, high stakes, lack of choice, emotions draining situation and little support from the management were found to be key stressors in the context of the workplace. Later, the effect was tested using regression analysis. It was found that the effect of long-hours duty and little support from management was negative and significant. These results triangulate with the findings of El Shikieri and Musa (2012); and Arbabisarjou et al., (2013). This implies that increasing the working hours would put an adverse effect on the performance of NICVD nurses. On the contrary, the effect of lack of choice is computed to be positively significant keeping all other factors constant. It is contradictory to the studies of Chatzigianni et al., (2018); Bakker and Demerouti (2017) which implies that limited choice available to NICVD nurses puts a positive effect on their performance. The underlying reason could be a comfortable organisational environment. However, this can be explored in future researches with qualitative analysis. 


\section{6) CONCLUSION}

Conclusively, it has been inferred that occupational stress affects employee performance and specifically nurses working at NICVD in a negative manner on an average. In this case, the variables including long-hours duty, little support from management and lack of choice were found to be highly significant. The findings, therefore, imply that the management needs to be supportive to enhance the performance of its nurses working at NICVD. In addition, the working hours are also needed to be maintained accordingly while providing them with personal space. However, a contrary aspect found was lack of choice affecting nurses' performance positively. Hence, providing them with limited flexibility within the organisation can keep the nurses intrigued by their work to serve patients more heartily.

\section{6) RECOMMENDATIONS}

In accordance with the findings, the following recommendations have been provided:

The management of NICVD needs to conduct stress management training at least once a month. Small weekly activities for nurses can work as a stimulator in this case as well.

The management should support the nurses by appreciating their work which can motivate them to serve better. This can work as a morale booster for nurses as well. The duty hours should be maintained by hiring additional staff and distributing the timings accordingly. This can limit the probability of occupational stress to a greater extent.

The nurses should be given personal time and this should be respected by the organisation.

\section{7) LIMITATIONS OF THE STUDY AND FUTURE DIRECTIONS}

The study was limited to the geographical bounds of Karachi and the specific institute considered in this aspect was National Institute of Cardiovascular Diseases (NICVD). Therefore, in future, other institutes and hospitals can be considered for the study while other cities of Pakistan can also be undertaken for research. Due to accessibility issues and timeconstraints, the sample was limited therefore, future researchers can use more sample size. In addition, this research focused on nurses therefore, other people like doctors can be considered in future researches. Also, a comparative analysis between doctors and nurses can be conducted underpinning occupational stress.

\section{REFERENCES}

Amin, M., Khattak, A. Z., \& Khan, M. Z. (2018). Effects of Job Stress on Employee Engagement and Organizational Commitment: A Study on Employees of Emergency Rescue Service Rescue 1122 District Peshawar. City University Research Journal, 8(2), 200-208.

Arbabisarjou, A., Ajdari, Z., Omeidi, K., \&Jalalinejad, R. (2013). The relationship between Job stress and performance among the hospitals Nurses. World Sci 
IBT JOURNAL OF BUSINESS STUDIES (IBT-JBS) Volume 16 Issue 1, 2020

$\mathrm{J}, 1,181-8$.

Asamoah-Appiah, W., \&Aggrey-Fynn, I. (2017). The impact of occupational stress on employee's performance: A study at Twifo oil palm plantation limited. African Journal of Applied Research (AJAR), 3(1), 14-25.

Badil, H. S., Ali, S. A., \& Siddiqui, M. A. (2017). Severity of Stress in Nurses Everyday Life in Karachi, Pakistan. Age (Years), 25(30), 125.

Bakker, A. B., \&Demerouti, E. (2017). Job demands-resources theory: Taking stock and looking forward. Journal of Occupational Health Psychology, 22(3), 273.

Beehr, T. A. (2014). Psychological stress in the workplace (psychology revivals). Routledge.

Beheshtifar, M., \&Nazarian, R. (2013). Role of occupational stress in organizations. Interdisciplinary Journal of Contemporary Research in Business, 4(9), 648-657.

Botha, E., Gwin, T., \&Purpora, C. (2015). The effectiveness of mindfulness based programs in reducing stress experienced by nurses in adult hospital settings: a systematic review of quantitative evidence protocol. JBI Database of Systematic Reviews and Implementation Reports, 13(10), 21-29. doi:10.11124/ jbisrir-2015-2380

Chatzigianni, D., Tsounis, A., Markopoulos, N., \&Sarafis, P. (2018). Occupational stress experienced by nurses working in a Greek Regional Hospital: A crosssectional study. Iranian journal of nursing and midwifery research, 23(6), 450.

El Shikieri, A. B., \& Musa, H. A. (2012). Factors associated with occupational stress and their effects on organizational performance in a Sudanese University. Creative Education, 3(01), 134.

Fay, D. S., \&Gerow, K. (2013). A biologist's guide to statistical thinking and analysis. WormBook: the online review of C. elegans biology, 1-54.

Gogtay, N. J., \&Thatte, U. M. (2017). Principles of correlation analysis. Journal of the association of physicians of India, 65(3), 78-81.

Golparvar, M., Kamkar, M., \&Javadian, Z. (2012). Moderating effects of job stress in emotional exhaustion and feeling of energy relationships with positive and negative behaviors: job stress multiple functions approach. International Journal of Psychological Studies, 4(4), 99.

Kanten, P., \&Yesiltas, M. (2015). The effects of positive and negative perfectionism on work engagement, psychological well-being and emotional exhaustion. Procedia Economics and Finance, 23(1), 1367-1375. 
Katić, I., Knežević, T., Berber, N., Ivanišević, A., \&Leber, M. (2019). The Impact of Stress on Life, Working, and Management Styles: How to Make an Organization Healthier?. Sustainability, 11(15), 4026.

Khamisa, N., Oldenburg, B., Peltzer, K., \&Ilic, D. (2015). Work related stress, burnout, job satisfaction and general health of nurses. International journal of environmental research and public health, 12(1), 652-666.

Lewig, K. A., \& Dollard, M. F. (2003). Emotional dissonance, emotional exhaustion and job satisfaction in call centre workers. European journal of work and organizational psychology, 12(4), 366-392.

Mahiri, E., \&Orwa, B. H. (2016). Occupational Stress and Employee Performance: A Case Study of Kenya National Highways Authority (KeNHA). International Journal of Education and Research, 4(1), 211-218.

Mustafa, M., Illzam, E. M., Muniandy, R. K., Hashmi, M. I., Sharifa, A. M., \& Nang, M. K. (2015). Causes and Prevention of Occupational Stress.IOSR Journal of Dental and Medical Sciences. 14(11), 98-104

Quick, J., \& Henderson, D. (2016). Occupational stress: Preventing suffering, enhancing wellbeing. International journal of environmental research and public health, 13(5), 459.

Ratnawat, R. G., \&Jha, P. C. (2014). Impact of job related stress on employee performance: a review and research agenda. Journal of Business and Management, 16(11), 1-16.

Roland, G. (2014). Occupational Stress Among Mauritian Nurses. International Journal of Emergency Trends in Science and Technology, 1(4), 463-476.

Schnall, P. L., Dobson, M., \& Landsbergis, P. (2016). Globalization, work, and cardiovascular disease. International Journal of Health Services, 46(4), 656692.

Shrivastava, A., \& Shukla, N. (2017). A Critical Review on Occupational Stress Factors Affecting Faculty Members Working in Higher Educational Institutions in India. Pacific Business Review International, 10(3), 129-138.

Ursachi, G., Horodnic, I. A., \&Zait, A. (2015). How reliable are measurement scales? External factors with indirect influence on reliability estimators. Procedia Economics and Finance, 20, 679-686.

Wu, G., Hu, Z., \& Zheng, J. (2019). Role Stress, Job Burnout, and Job Performance in Construction Project Managers: The Moderating Role of Career Calling. International journal of environmental research and public health, 16(13), 2394. 